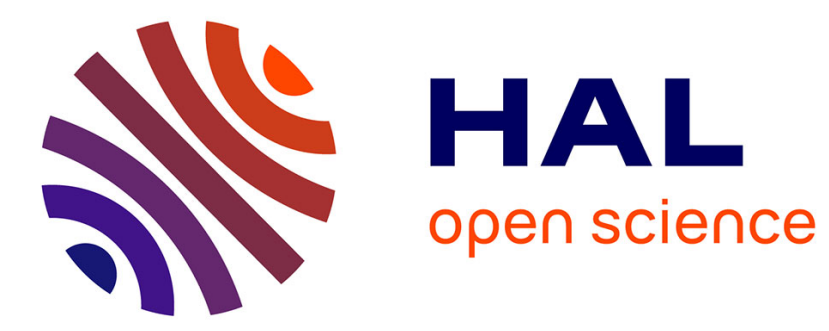

\title{
New Gilman-type lithium cuprate from a copper(II) salt: synthesis and deprotonative cupration of aromatics
}

Nguyen Tan Tai, Floris Chevallier, Viatcheslav Jouikov, Florence Mongin

\section{To cite this version:}

Nguyen Tan Tai, Floris Chevallier, Viatcheslav Jouikov, Florence Mongin. New Gilman-type lithium cuprate from a copper(II) salt: synthesis and deprotonative cupration of aromatics. Tetrahedron Letters, 2009, 50 (49), pp.6787-6790. 10.1016/j.tetlet.2009.09.100 . hal-00785023

\section{HAL Id: hal-00785023 https://hal.science/hal-00785023}

Submitted on 5 Feb 2013

HAL is a multi-disciplinary open access archive for the deposit and dissemination of scientific research documents, whether they are published or not. The documents may come from teaching and research institutions in France or abroad, or from public or private research centers.
L'archive ouverte pluridisciplinaire HAL, est destinée au dépôt et à la diffusion de documents scientifiques de niveau recherche, publiés ou non, émanant des établissements d'enseignement et de recherche français ou étrangers, des laboratoires publics ou privés. 


\section{Graphical Abstract}

\begin{tabular}{|c|c|c|c|}
\hline $\begin{array}{l}\text { New Gilman-type lithium cuprate from a } \\
\text { copper(II) salt: synthesis and deprotonative } \\
\text { cupration of aromatics }\end{array}$ & \multicolumn{3}{|c|}{ Leave this area blank for abstract info. } \\
\hline $\begin{array}{l}\text { Tan Tai Nguyen, Floris Chevallier, Viatcheslav Jouikov } \\
\text { and Florence Mongin }\end{array}$ & \multirow[b]{2}{*}{$\mathrm{Ar}-\mathrm{H}$} & $\begin{array}{l}\text { 1) (TMP) }{ }_{2} \mathrm{CuLi} \text { (1 equiv) } \\
\mathrm{THF}, \mathrm{rt}, 2 \mathrm{~h}\end{array}$ & \\
\hline $\begin{array}{l}\text { Chimie et Photonique Moléculaires } \\
\text { UMR } 6510 \text { CNRS, Université de Rennes } 1 \\
\text { Bâtiment 10A, Case 1003, Campus de Beaulieu } \\
35042 \text { Rennes Cedex (France) }\end{array}$ & & 2) Electrophile or $\mathrm{PhNO}_{2}$ & $\begin{array}{l}\mathrm{Ar}-\mathrm{E} \\
\mathrm{E}=\mathrm{I}, \mathrm{CH}_{2} \mathrm{CH}=\mathrm{CH}_{2}, \\
\quad \mathrm{COAr}, \mathrm{CH}_{3}, \mathrm{Ar}\end{array}$ \\
\hline
\end{tabular}




\title{
New Gilman-type lithium cuprate from a copper(II) salt: synthesis and deprotonative cupration of aromatics
}

\author{
Tan Tai Nguyen, Floris Chevallier, Viatcheslav Jouikov* and Florence Mongin* \\ Chimie et Photonique Moléculaires, UMR 6510 CNRS, Université de Rennes 1, Bâtiment 10A, Case 1003 \\ Campus Scientifique de Beaulieu, 35042 Rennes Cedex (France)
}

\begin{abstract}
Deprotonative cupration of aromatics including heterocycles (anisole, 1,4-dimethoxybenzene, thiophene, furan, 2fluoropyridine, 2-chloropyridine, 2-bromopyridine and 2,4-dimethoxypyrimidine) was realized in tetrahydrofuran at room temperature using the Gilman-type amido-cuprate (TMP) $)_{2} \mathrm{CuLi}$ in situ prepared from $\mathrm{CuCl}_{2} \cdot \mathrm{TMEDA}$ through successive addition of 1 equivalent of butyllithium and 2 equivalents of LiTMP. The intermediate lithium (hetero)arylcuprates were evidenced by trapping with iodine, allyl bromide, methyl iodide and benzoyl chlorides, the latter giving the best results. Symmetrical dimers were also prepared from lithium azine and diazine cuprates using nitrobenzene as oxidative agent.

(C) 2013 Elsevier Science. All rights reserved
\end{abstract}

Keywords: lithium; copper; metalation; aromatic compound; heterocycle

Lithium bases have been largely employed for the deprotometalation of aromatic rings. ${ }^{1}$ Even if less nucleophilic hindered lithium dialkylamides are more suitable for the metalation of aromatics bearing reactive functions or sensitive $\pi$-deficient heterocycles, low reaction temperatures are required due to the high reactivity of the corresponding (hetero)aryllithiums.

The use of bimetallic bases in order to get more efficient and/or more chemoselective reactions is a challenging field. LICKOR (LIC $=$ butyllithium, $\mathrm{KOR}=$ potassium tert-butoxide) first described by Schlosser ${ }^{2}$ and Lochmann, ${ }^{3}$ and BuLi-LiDMAE (DMAE $=2$-dimethylaminoethoxide) introduced by Caubère ${ }^{4}$ and developed further by Gros and Fort in the pyridine series ${ }^{5}$ are well-known examples of synergic (or superbasic) mixtures of organolithiums and alkali metal alkoxides. By combining soft organometallic compounds with alkali (or alkaline-earth metal) additives, bases have been more recently prepared and used to generate functionalized aromatic compounds including heterocycles. ${ }^{6}$ Examples are $\mathrm{R}_{2} \mathrm{Zn}(\mathrm{TMP}) \mathrm{Li}(\cdot \mathrm{TMEDA})\left(\mathrm{R}={ }^{t} \mathrm{Bu}\right.$, $\mathrm{Bu}$; TMP $=$ 2,2,6,6-tetramethylpiperidino, TMEDA $=N, N, N^{\prime}, N^{\prime}-$ tetramethylethylenediamine) (described by the groups of Kondo, Uchiyama, Mulvey and Hevia), ${ }^{7}(\mathrm{TMP})_{2} \mathrm{Zn} \cdot 2 \mathrm{MgCl}_{2} \cdot 2 \mathrm{LiCl}^{8}$ and TMPZnCl $\cdot \mathrm{LiCl}^{9} \quad$ (Knochel), ${ }^{i} \mathrm{Bu}_{3} \mathrm{Al}(\mathrm{TMP}) \mathrm{Li} \quad$ (Uchiyama and Mulvey), ${ }^{10} \mathrm{Al}(\mathrm{TMP})_{3} \cdot 3 \mathrm{LiCl}$ (Knochel), ${ }^{11}\left(\mathrm{Me}_{3} \mathrm{SiCH}_{2}\right)_{2} \mathrm{Mn}$ (TMP)$\mathrm{Li} \cdot \mathrm{TMEDA}$ (Mulvey), ${ }^{12}$ and $\mathrm{MeCu}(\mathrm{TMP})(\mathrm{CN}) \mathrm{Li}_{2}$ (Uchiyama and Wheatley). ${ }^{13}$

We recently accomplished the deproto-metalation of a large range of aromatics including heterocycles using a newly developed lithium-cadmium base, (TMP) ${ }_{3} \mathrm{CdLi}$, in situ prepared from $\mathrm{CdCl}_{2}$.TMEDA and 3 equivalents of LiTMP. ${ }^{14}$ We here describe the synthesis of putative (TMP) ${ }_{2} \mathrm{CuLi}$ using the same approach, and its use to deprotonate aromatic substrates.

Wheatley and Uchiyama documented in 2007 the first direct metalation using a lithium cuprate. ${ }^{13}$ The authors showed that Gilman-type amidocuprates prepared from $\mathrm{CuI}$ were less efficient bases than Lipshutz-type amidocuprates prepared from $\mathrm{CuCN}$. $\mathrm{MeCu}(\mathrm{TMP})(\mathrm{CN}) \mathrm{Li}_{2}$ was identified as the best base when used at the rate of 2 equivalents in tetrahydrofuran (THF) at $0^{\circ} \mathrm{C}$.

Our approach was based on the in situ generation of putative (TMP) ${ }_{2} \mathrm{CuLi}$ from $\mathrm{CuCl}_{2} \cdot \mathrm{TMEDA}^{15}$ by (i) reduction of $\mathrm{Cu}$ (II) to $\mathrm{Cu}(\mathrm{I})$ and (ii) formation of the lithium cuprate by addition of two equivalents of LiTMP. The reaction of copper(II) chloride with lithium bis(trimethylsilyl)amide at the reflux temperature of THF being known to produce the corresponding copper(I) amide, ${ }^{16}$ the generation of $(\mathrm{TMP})_{2} \mathrm{CuLi}$ starting from $\mathrm{CuCl}_{2}$. TMEDA and using 3 equivalents of LiTMP was first considered. Electron paramagnetic resonance (EPR) response of $\mathrm{Cu}(\mathrm{II})$ was used in order to check the validity of the reduction step using LiTMP. To this purpose, the EPR spectrum of a THF solution prepared from $\mathrm{CuCl}_{2}$. TMEDA and LiTMP $\left(2.10^{-3} \mathrm{M}\right.$ each) was collected, and compared with a spectrum recorded from a THF solution of $\mathrm{CuCl}_{2} \cdot$ TMEDA $\left(2.10^{-3} \mathrm{M}\right)$. It was observed that the reduction to $\mathrm{Cu}(\mathrm{I})$ was not quantitative, even after 20 hours at room temperature, and that TEMPO was formed, probably by reaction between LiTMP and dissolved oxygen ${ }^{17}$ (Figure 1). ${ }^{18}$ It was then

*Fax: +33-(0)2-2323-6955; e-mail: viatcheslav.jouikov@univ-rennes1.fr

* Corresponding author. Fax: +33-(0)2-2323-6955; e-mail: florence.mongin@univ-rennes1.fr 
decided to attempt the use of butyllithium for the reduction of $\mathrm{CuCl}_{2} \cdot \mathrm{TMEDA}$ at $0^{\circ} \mathrm{C}$, and the EPR spectrum of a THF solution prepared from $\mathrm{CuCl}_{2}$. TMEDA and $\mathrm{BuLi}\left(2.10^{-3} \mathrm{M}\right.$ each) was recorded. The spectrum showing a complete reduction of $\mathrm{Cu}(\mathrm{II})$, we prepared the mixed lithium-copper base as depicted in Scheme 1 , and recorded again the spectra of the solution. The only observable signal being attributed to TEMPO, ${ }^{19}$ the reactivity of such prepared $(\mathrm{TMP})_{2} \mathrm{CuLi}$ was studied towards various aromatics.

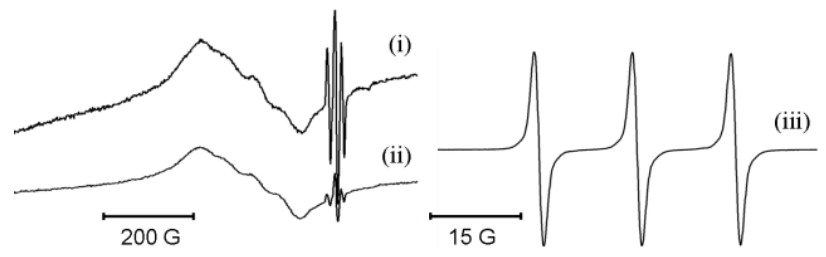

Figure 1. EPR spectra of (i) a THF solution prepared from $\mathrm{CuCl}_{2} \cdot$ TMEDA and LiTMP $\left(2.10^{-3} \mathrm{M}\right.$ each), (ii) the same solution $20 \mathrm{~h}$ later and (iii) a THF solution of TEMPO $\left(\mathrm{g}=2.007, a_{\mathrm{N}}=15.54 \mathrm{G}\right)$.

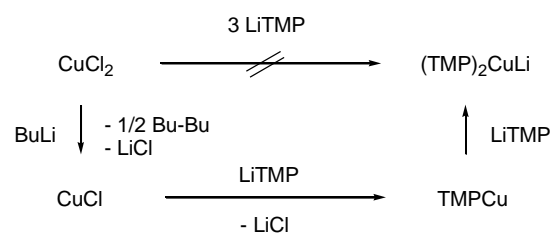

Scheme 1. Synthesis of (TMP) $)_{2} \mathrm{CuLi}$ from $\mathrm{CuCl}_{2} \cdot \mathrm{TMEDA}$ as copper(II) source.

Table 1. Deproto-cupration of 1a,b followed by trapping with electrophiles.

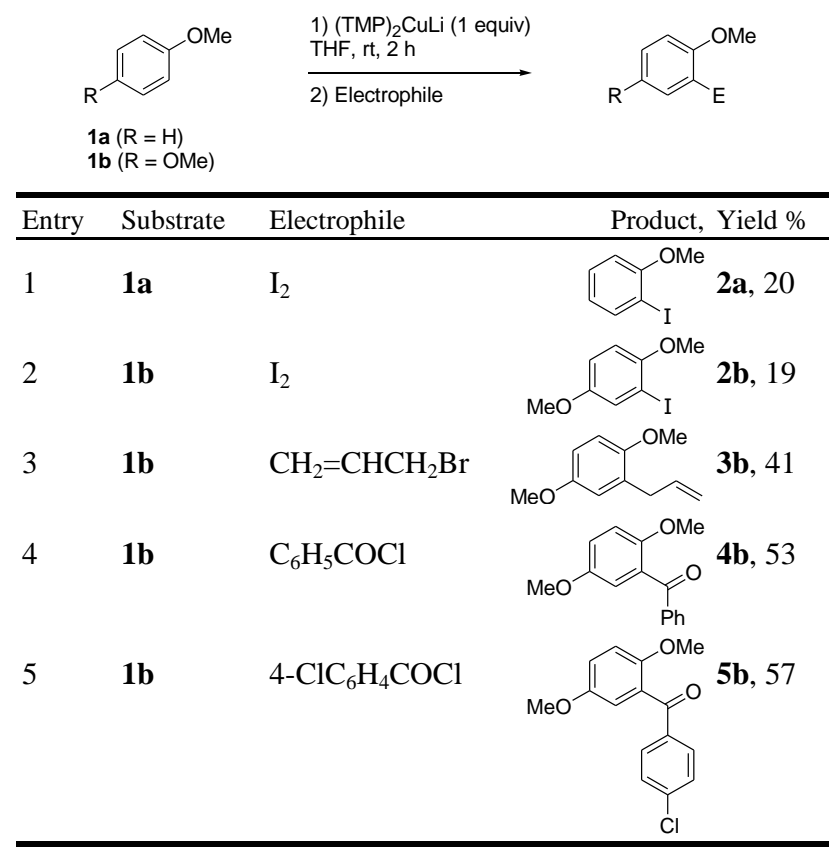

With anisole (1a) and the 4-methoxy derivative $\mathbf{1 b}$ as substrate, the metalation reactions performed in THF at room temperature by using 1 equivalent of in situ prepared $(\mathrm{TMP})_{2} \mathrm{CuLi}$, followed by subsequent trapping with elemental iodine after $2 \mathrm{~h}$, proceeded in low yields (compounds $\mathbf{2} \mathbf{a}^{20}$ and $\mathbf{2 b},{ }^{21}$ Table 1, entries 1,2). Concomitant formation of 2,2'dimethoxybiphenyl ${ }^{22}$ and $N$-(2-methoxyphenyl)-2,2,6,6tetramethylpiperidine ${ }^{23}$ was observed from anisole (1a), probably through reactions occurring during the trapping step with iodine. Indeed, it was noted that carrying out the reaction using water as electrophile instead of iodine resulted in recovered anisole. Whereas the use of ethyl acrylate and enones such as 2cyclohexen-1-one and 2-cyclopenten-1-one did not allow any trapping products, reactions proved successful when performed with allyl bromide and benzoyl chlorides at the reflux temperature of THF (entries 3-5) to afford the allylated derivative $\mathbf{3 b},{ }^{24}$ and the benzophenones $\mathbf{4} \mathbf{b}^{25}$ and $\mathbf{5} \mathbf{b}^{26}$ in yields ranging from 41 to $57 \%$.

We next demonstrated that the cuprate base was suitable for the metalation of both $\pi$-excessive and $\pi$-deficient aromatic heterocycles. Thiophene $(\mathbf{6 a})$ and furan $(\mathbf{6 b})$ proved to react under the same reaction conditions to furnish after trapping with benzoyl chlorides the expected ketones $\mathbf{7 a},{ }^{20} \mathbf{8} \mathbf{a}^{27}$ and $\mathbf{7} \mathbf{b}^{27}$ (Scheme 2).
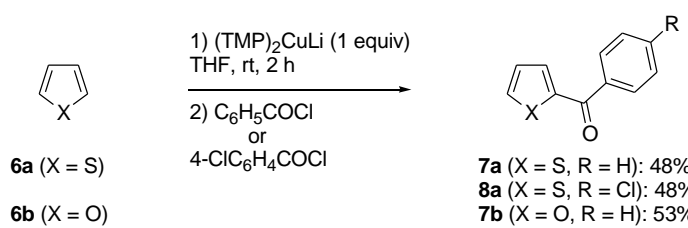

$7 a(X=S, R=H): 48 \%$
$8 a(X=S, R=C l): 48 \%$ $7 \mathbf{b}(X=O, R=H): 53 \%$

Scheme 2. Deproto-cupration of $\mathbf{6 a}, \mathbf{b}$ followed by trapping with benzoyl chlorides.

2-Halopyridines 9a-c were similarly successively treated with the amido-cuprate and benzoyl chlorides. Whereas a low $20 \%$ yield (compound 10c) ${ }^{28}$ was obtained starting from 2bromopyridine (9c) and using benzoyl chloride, side reactions were not observed with its lighter isomers $\mathbf{9 a}, \mathbf{b}$, and the expected ketones $\mathbf{1 0 a},{ }^{29} \mathbf{1 0 b} \mathbf{b}^{30}$ and $\mathbf{1 1} \mathbf{a}^{31}$ were isolated in good yields. Using iodine as electrophile in the case of 2-fluoropyridine (9a) resulted in the formation of the iodide $\mathbf{1 2} \mathbf{a}^{20}$ in a moderate $31 \%$ yield due to the concomitant formation of the 3,3'-dimer $\mathbf{1 3 a} \mathbf{a}^{32}$ The latter was obtained in a high $84 \%$ yield using nitrobenzene, ${ }^{33}$ which proved to be in this reaction a better oxidant than iodine (Table 2).

2,4-Dimethoxypyrimidine (14) was finally similarly involved in the reaction to afford after subsequent trapping with benzoyl chlorides, allyl bromide and iodomethane the regioselectively functionalized derivatives $\mathbf{1 5 - 1 8}$ in yields ranging from 19 to $52 \% ;^{34}$ the corresponding 5,5'-dimer $\mathbf{1 9}$ also formed using nitrobenzene as oxidative agent (Scheme 3 ).

Table 2. Deproto-cupration of $\mathbf{9 a - c}$ followed by trapping with electrophiles or oxidation.

$$
\begin{aligned}
& \text { 1) (TMP) } \mathrm{CuLi} \text { (1 equiv) } \\
& 9 \mathrm{a}(\mathrm{X}=\mathrm{F}) \\
& 9 \mathrm{~b}(\mathrm{X}=\mathrm{Cl}) \\
& 9 \mathrm{R}(\mathrm{R}=\mathrm{Br})
\end{aligned}
$$

\begin{tabular}{|c|c|c|c|}
\hline Entry & Substrate & $\begin{array}{l}\text { Electrophile or } \\
\text { oxidative agent }\end{array}$ & Product, Yield \% \\
\hline
\end{tabular}




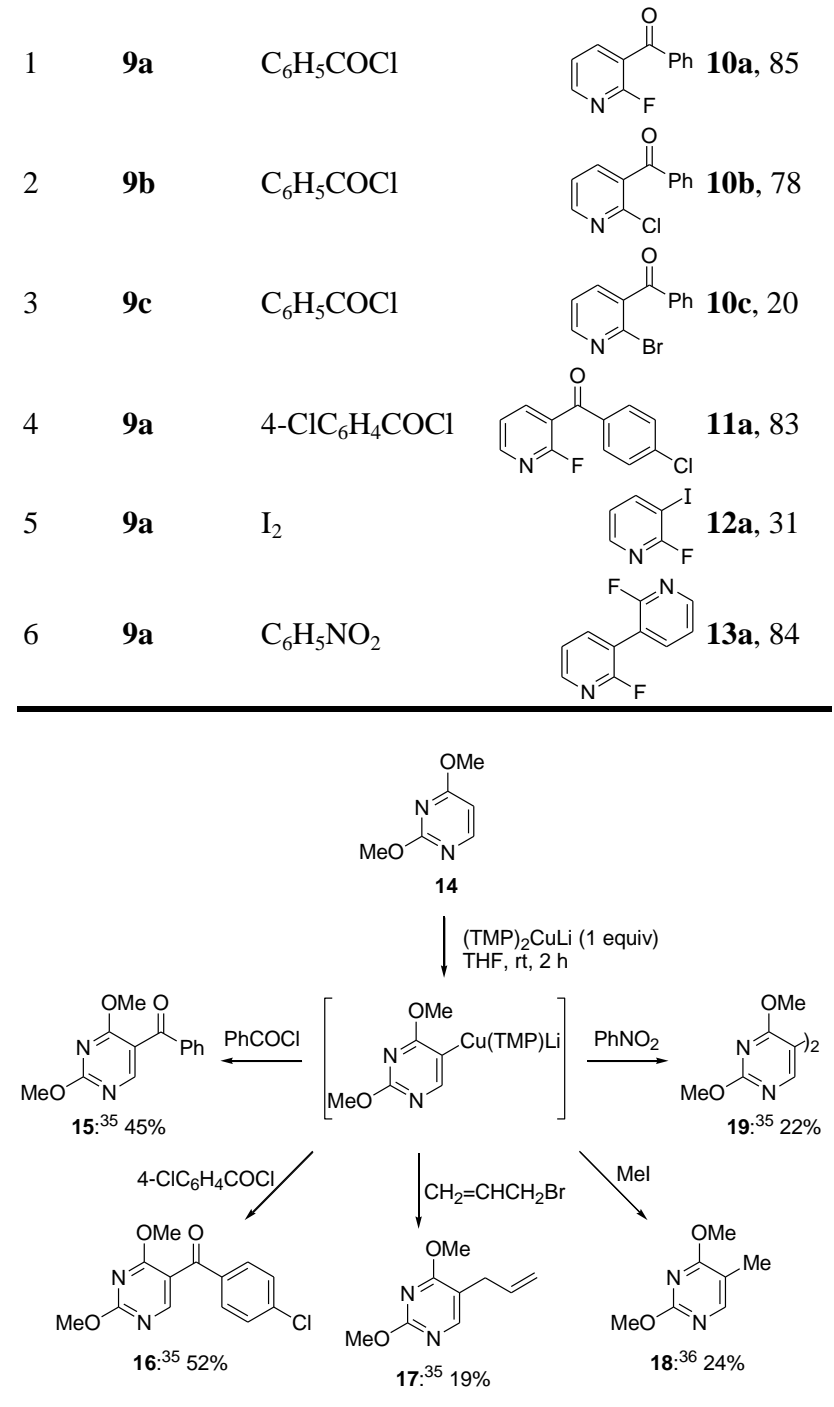

Scheme 3. Deproto-cupration of $\mathbf{1 4}$ followed by trapping with electrophiles or oxidation.

In summary, deprotonative cupration of aromatics was realized using a Gilman-type amido-cuprate in situ prepared from stable $\mathrm{CuCl}_{2} \cdot$ TMEDA. $^{37}$ The intermediate lithium arylcuprates were notably evidenced by trapping with benzoyl chlorides in satisfying yields.

Further development will notably concern the impact of TEMPO on reaction yields. Indeed, it is known from the literature that TEMPO is an excellent ligand for alkali metals, and its presence in TMP-containing complexes can modify the availability of the amido groups. ${ }^{38}$

\section{Acknowledgment}

We gratefully acknowledge the financial support of MESR of France (to T. T. N.).

\section{References and Notes}

1. a) Gschwend, H. W.; Rodriguez, H. R. Org. React. 1979, 26, 1-360. b) Beak, P.; Snieckus, V. Acc. Chem. Res. 1982, 15,
306-312. c) Snieckus, V. Chem. Rev. 1990, 90, 879-933. d) Gant, T. G.; Meyers, A. I. Tetrahedron 1994, 50, 2297-2360. e) Schlosser, M. Organometallics in Synthesis, 2nd ed. (Ed.: M. Schlosser), Wiley, 2002, Chapter I.

2. Schlosser, M. Pure Appl. Chem. 1988, 60, 1627-1634.

3. Lochmann, L. Eur. J. Inorg. Chem. 2000, 1115-1126.

4. Caubère, P. Chem. Rev. 1993, 93, 2317-2334.

5. Gros, P.; Fort, Y. Eur. J. Org. Chem. 2002, 3375-3383.

6. For reviews, see: a) Mulvey, R. E. Organometallics 2006, 25, 1060-1075; b) Mulvey, R. E.; Mongin, F.; Uchiyama, M.; Kondo, Y. Angew. Chem. Int. Ed. 2007, 46, 3802-3824; c) Mulvey, R. E. Acc. Chem. Res. 2009, 42, 743-755.

7. a) Kondo, Y.; Shilai, M.; Uchiyama, M.; Sakamoto, T. J. Am. Chem. Soc. 1999, 121, 3539-3540. b) Uchiyama, M.; Miyoshi, T.; Kajihara, Y.; Sakamoto, T.; Otani, Y.; Ohwada, T.; Kondo, Y. J. Am. Chem. Soc. 2002, 124, 8514-8515. c) Barley, H. R. L.; Clegg, W.; Dale, S. H.; Hevia, E.; Honeyman, G. W.; Kennedy, A. R.; Mulvey, R. E. Angew. Chem. Int. Ed. 2005, 44, 6018-6021. d) Clegg, W.; Dale, S. H.; Hevia, E.; Honeyman, G. W.; Mulvey, R. E. Angew. Chem. Int. Ed. 2006, 45, 2370-2374. e) Clegg, W.; Dale, S. H.; Harrington, R. W.; Hevia, E.; Honeyman, G. W.; Mulvey, R. E. Angew. Chem. Int. Ed. 2006, 45, 2374-2377. f) Clegg, W.; Dale, S. H.; Drummond, A. M.; Hevia, E.; Honeyman, G. W.; Mulvey, R. E. J. Am. Chem. Soc. 2006, 128, 7434-7435. g) Uchiyama, M.; Kobayashi, Y.; Furuyama, T.; Nakamura, S.; Kajihara, Y.; Miyoshi, T.; Sakamoto, T.; Kondo, Y.; Morokuma, K. J. Am. Chem. Soc. 2008, 130, 472-480. h) Clegg, W.; Conway, B.; Hevia, E.; McCall, M. D.; Russo, L.; Mulvey, R. E. J. Am. Chem. Soc. 2009, 131, 2375-2384.

8. a) Wunderlich, S. H.; Knochel, P. Angew. Chem. Int. Ed. 2007, 46, 7685-7688. b) Wunderlich, S.; Knochel, P. Chem. Commun. 2008, 6387-6389. c) Wunderlich, S. H.; Knochel, P. Org. Lett. 2008, 10, 4705-4707. d) Mosrin, M.; Knochel, P. Chem. Eur. J. 2009, 15, 1468-1477.

9. Mosrin, M.; Knochel, P. Org. Lett. 2009, 11, 1837-1840.

10. a) Uchiyama, M.; Naka, H.; Matsumoto, Y.; Ohwada, T. J. Am. Chem. Soc. 2004, 126, 10526-10527. b) Garcia-Alvarez, J.; Graham, D. V.; Kennedy, A. R.; Mulvey, R. E.; Weatherstone, S. Chem. Commun. 2006, 30, 3208-3210. c) Garcia-Alvarez, J.; Hevia, E.; Kennedy, A. R.; Klett, J.; Mulvey, R. E. Chem. Commun. 2007, 2402-2404. d) Conway, B.; Hevia, E.; García-Álvarez, J.; Graham, D. V.; Kennedy, A. R.; Mulvey, R. E. Chem. Commun. 2007, 52415243. e) Naka, H.; Uchiyama, M.; Matsumoto, Y.; Wheatley, A. E. H.; McPartlin, M.; Morey, J. V.; Kondo, Y. J. Am. Chem. Soc. 2007, 129, 1921-1930. f) Naka, H.; Morey, J. V.; Haywood, J.; Eisler, D. J.; McPartlin, M.; Garcia, F.; Kudo, H.; Kondo, Y.; Uchiyama, M.; Wheatley, A. E. H. J. Am. Chem. Soc. 2008, 130, 16193-16200.

11. Wunderlich, S. H.; Knochel, P. Angew. Chem. Int. Ed. 2009, $48,1501-1504$.

12. Garcia-Álvarez, J.; Kennedy, A. R.; Klett, J.; Mulvey, R. E. Angew. Chem. Int. Ed. 2007, 46, 1105-1108.

13. Usui, S.; Hashimoto, Y.; Morey, J. V.; Wheatley, A. E. H.; Uchiyama, M. J. Am. Chem. Soc. 2007, 129, 15102-15103.

14. a) L'Helgoual'ch, J.-M.; Bentabed-Ababsa, G.; Chevallier, F.; Yonehara, M.; Uchiyama, M.; Derdour, A.; Mongin, F. Chem. Commun. 2008, 5375-5377. b) Snégaroff, K.; L'Helgoual'ch, J.-M.; Bentabed-Ababsa, G.; Nguyen, T. T.; Chevallier, F.; Yonehara, M.; Uchiyama, M.; Derdour, A.; Mongin, F. Chem. Eur. J., in press. See also: c) L'Helgoual'ch, J.-M.; Bentabed-Ababsa, G.; Chevallier, F.; Derdour, A.; Mongin, F. Synthesis 2008, 4033-4035; d) Bentabed-Ababsa, G.; Blanco, F.; Derdour, A.; Mongin, F.; Trécourt, F.; Quéguiner, G.; Ballesteros, R.; Abarca, B. J. Org. Chem. 2009, 74, 163-169. 
15. We chose $\mathrm{CuCl}_{2}$ as copper salt source instead of $\mathrm{CuCl}$ because of its higher air stability. In addition, the presence of TMEDA makes salts less sensitive to moisture, and sometimes favors deprotonation reactions: see references $7 \mathrm{~d}$ f. For the synthesis of $\mathrm{CuCl}_{2}$. TMEDA, see: Handley, D. A.; Hitchcock, P. B.; Lee, T. H.; Leigh, G. J. Inorg. Chem. Acta 2001, 316, 59-64.

16. James, A. M.; Laxman, R. V.; Fronczek, F. R.; Maverick, A. W. Inorg. Chem. 1998, 37, 3785-3791.

17. The reaction of lithiated organics with molecular oxygen is well-documented: Wheatley, A. E. H. Chem. Soc. Rev. 2001, $30,265-273$. The process is thought to involve a radical chain decomposition in which a peroxide intermediate degrades to an organooxide product.

18. An organic radical was also observed $\left(\mathrm{g}=2.005, a_{\mathrm{H}}=1.096\right.$ $\mathrm{G}, 2 \mathrm{H})$, but was not identified:

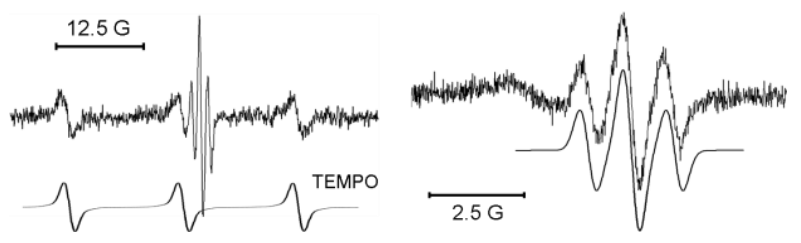

19. TEMPO is similarly formed by preparing LiTMP in THF.

20. The spectral data are analogous to those obtained from a commercial sample.

21. The ${ }^{1} \mathrm{H}$ NMR data are analogous to those described: AzadiArdakani, M.; Wallace, T. W. Tetrahedron 1988, 44, 59395952.

22. The physical and spectral data are analogous to those previously described: Yuan, Y.; Bian, Y. Appl. Organomet. Chem. 2008, 22, 15-18.

23. ${ }^{1} \mathrm{H}$ NMR (300 MHz, $\left.\mathrm{CDCl}_{3}\right): \delta 0.78(\mathrm{~s}, 6 \mathrm{H}), 1.23$ (s, $\left.6 \mathrm{H}\right)$, 1.49-1.64 (m, 6H), 3.75 (s, 3H), 6.82-6.88 (m, 2H), 7.13-7.19 $(\mathrm{m}, 1 \mathrm{H}), 7.29(\mathrm{dd}, 1 \mathrm{H}, \mathrm{J}=8.3$ and $1.9 \mathrm{~Hz}) ;{ }^{13} \mathrm{C}$ NMR $(75$ $\left.\mathrm{MHz}, \mathrm{CDCl}_{3}\right): \delta 18.6,26.0,31.5,41.8,54.4,55.1,111.0$, 119.3, 126.4, 134.2, 136.0, 160.3.

24. The ${ }^{1} \mathrm{H}$ NMR data are analogous to those described: Ochiai, M.; Fujita, E.; Arimoto, M.; Yamaguchi, H. Chem. Pharm. Bull. 1982, 30, 3994-3999.

25. The ${ }^{1} \mathrm{H}$ NMR data are analogous to those described: Chen, $X$.; Yu, M.; Wang, M. J. Chem. Res. 2005, 80-81.

26. The spectral data are analogous to those previously described: Waterlot, C.; Hasiak, B.; Couturier, D.; Rigo, B. Tetrahedron 2001, 57, 4889-4901.

27. The spectral data are analogous to those previously described: Rao, M. L. N.; Venkatesh, V.; Banerjee, D. Tetrahedron 2007, 63, 12917-12926.

28. The spectral data are analogous to those previously described: Inamoto, K.; Katsuno, M.; Yoshino, T.; Arai, Y.; Hiroya, K.; sakamoto, T. Tetrahedron 2007, 63, 2695-2711.

29. The ${ }^{1} \mathrm{H}$ NMR data are analogous to those described: Güngör, T.; Marsais, F.; Quéguiner, G. J. Organomet. Chem. 1981, $215,139-150$.

30. The ${ }^{1} \mathrm{H}$ NMR data are analogous to those described: Trécourt, F.; Marsais, F.; Güngör, T.; Quéguiner, G. J. Chem. Soc., Perkin Trans. 1 1990, 2409-2415.

31. Compound 11a: yellow powder; mp $90{ }^{\circ} \mathrm{C} ;{ }^{1} \mathrm{H}$ NMR (300 $\mathrm{MHz}, \mathrm{CDCl}_{3}$ ): $\delta 7.37$ (ddd, $1 \mathrm{H}, \mathrm{J}=7.6,4.9$ and $1.9 \mathrm{~Hz}$ ), 7.44$7.50(\mathrm{~m}, 2 \mathrm{H}), 7.73-7.79(\mathrm{~m}, 2 \mathrm{H}), 8.04(\mathrm{ddd}, 1 \mathrm{H}, \mathrm{J}=9.4,7.5$ and $2.0 \mathrm{~Hz}), 8.43(\mathrm{ddd}, 1 \mathrm{H}, \mathrm{J}=4.9,2.1$ and $1.2 \mathrm{~Hz}) ;{ }^{13} \mathrm{C}$
NMR (75 MHz, $\left.\mathrm{CDCl}_{3}\right): \delta 121.3(\mathrm{~d}, \mathrm{~J}=30 \mathrm{~Hz}), 121.9(\mathrm{~d}, \mathrm{~J}=$ $4.5 \mathrm{~Hz}), 129.2(\mathrm{~s}, 2 \mathrm{C}), 131.1(\mathrm{~d}, 2 \mathrm{C}, \mathrm{J}=1.2 \mathrm{~Hz}), 135.0(\mathrm{~d}, \mathrm{~J}=$ $0.9 \mathrm{~Hz}), 140.7$ (s), $142.0(\mathrm{~d}, \mathrm{~J}=3.3 \mathrm{~Hz}), 150.9$ (d, J = 15 Hz), $160.1(\mathrm{~d}, \mathrm{~J}=243 \mathrm{~Hz}), 190.7(\mathrm{~d}, \mathrm{~J}=4.9 \mathrm{~Hz})$.

32. Compound 13a: beige powder; $\mathrm{mp} 153{ }^{\circ} \mathrm{C} ;{ }^{1} \mathrm{H}$ NMR $(300$ $\left.\mathrm{MHz}, \mathrm{CDCl}_{3}\right): \delta$ 7.31-7.36 (m, 2H), 7.88-7.96 (m, 2H), 8.30 $(\mathrm{dd}, 2 \mathrm{H}, \mathrm{J}=4.9$ and $1.9 \mathrm{~Hz}) ;{ }^{13} \mathrm{C}$ NMR $\left(75 \mathrm{MHz}, \mathrm{CDCl}_{3}\right): \delta$ 116.7 (m), 121.7 (m), $142.0(\mathrm{t}, \mathrm{J}=3.3 \mathrm{~Hz}), 148.1(\mathrm{~m}), 160.4$ $(\mathrm{d}, \mathrm{J}=241 \mathrm{~Hz})$.

33. Mandeville, W. H.; Whitesides, G. M. J. Org. Chem. 1974, $39,400-405$.

34. Even if the basicity of pyrimidine nitrogens is low compared with that of pyridine, competitive quaternarization by reaction with allyl bromide and methyl iodide is not impossible under the conditions used.

35. Compound 15: yellow oil; ${ }^{1} \mathrm{H}$ NMR $\left(300 \mathrm{MHz}, \mathrm{CDCl}_{3}\right)$ : $\delta$ $3.95(\mathrm{~s}, 3 \mathrm{H}), 4.07(\mathrm{~s}, 3 \mathrm{H}), 7.42-7.49(\mathrm{~m}, 2 \mathrm{H}), 7.58(\mathrm{tt}, 1 \mathrm{H}, \mathrm{J}=$ 7.3 and $1.3 \mathrm{~Hz}), 7.74-7.78(\mathrm{~m}, 2 \mathrm{H}), 8.46(\mathrm{br} \mathrm{s}, 1 \mathrm{H}),{ }^{13} \mathrm{C} \mathrm{NMR}$ $\left(75 \mathrm{MHz}, \mathrm{CDCl}_{3}\right): \delta 54.5,55.5,114.5,128.5(2 \mathrm{C}), 129.7$ (2C), 133.3, 137.6, 161.2, 166.3, 169.3, 192.2.

Compound 16: yellow powder; mp 145-146 ${ }^{\circ} \mathrm{C} ;{ }^{1} \mathrm{H}$ NMR (300 $\left.\mathrm{MHz}, \mathrm{CDCl}_{3}\right): \delta 8.48(\mathrm{~s}, 1 \mathrm{H}), 7.68-7.73(\mathrm{~m}, 2 \mathrm{H}), 7.41-7.46$ $(\mathrm{m}, 2 \mathrm{H}), 4.08(\mathrm{~s}, 3 \mathrm{H}), 3.96(\mathrm{~s}, 3 \mathrm{H}) ;{ }^{13} \mathrm{C} \mathrm{NMR}(75 \mathrm{MHz}$, $\mathrm{CDCl}_{3}$ ): $\delta 54.5,55.5,114.1,128.8(2 \mathrm{C}), 130.9(2 \mathrm{C}), 136.0$, 139.7, 161.3, 166.5, 169.1, 190.9.

Compound 17: yellow oil; ${ }^{1} \mathrm{H}$ NMR $\left(300 \mathrm{MHz}, \mathrm{CDCl}_{3}\right)$ : $\delta$ $3.22(\mathrm{~m}, 2 \mathrm{H}), 3.96(\mathrm{~s}, 3 \mathrm{H}), 3.97(\mathrm{~s}, 3 \mathrm{H}), 5.00-5.08(\mathrm{~m}, 2 \mathrm{H})$, 5.82-5.97 (m, 1H), 7.98 (br s, 1H); ${ }^{13} \mathrm{C}$ NMR $(75 \mathrm{MHz}$, $\left.\mathrm{CDCl}_{3}\right): \delta 29.8,54.0,54.8,113.6,116.5,135.2,157.0,164.4$, 169.4 .

Compound 19: red powder; $\mathrm{mp} 209^{\circ} \mathrm{C} ;{ }^{1} \mathrm{H}$ NMR $(300 \mathrm{MHz}$, $\left.\mathrm{CDCl}_{3}\right): \delta 3.97(\mathrm{~s}, 6 \mathrm{H}), 4.03(\mathrm{~s}, 6 \mathrm{H}), 8.20(\mathrm{~s}, 2 \mathrm{H}) ;{ }^{13} \mathrm{C} \mathrm{NMR}$ $\left(75 \mathrm{MHz}, \mathrm{CDCl}_{3}\right): \delta 54.3(2 \mathrm{C}), 55.0(2 \mathrm{C}), 108.3(2 \mathrm{C}), 158.8$ (2C), 165.1 (2C), 168.7 (2C).

36. The spectral data are analogous to those previously described Boudet, N.; Dubbaka, S. R.; Knochel, P. Org. Lett. 2008, 10, $1715-1718$.

37. Typical procedure: To a stirred, cooled $\left(0^{\circ} \mathrm{C}\right)$ suspension of $\mathrm{CuCl}_{2} \cdot$ TMEDA $(0.25 \mathrm{~g}, 1.0 \mathrm{mmol})$ in THF $(5 \mathrm{~mL})$ were successively added BuLi (about 1.6 M hexanes solution, 1.0 $\mathrm{mmol}$ ) and, $15 \mathrm{~min}$ later, a solution of LiTMP prepared in THF $(2 \mathrm{~mL})$ at $0^{\circ} \mathrm{C}$ from 2,2,6,6-tetramethylpiperidine ( 0.34 $\mathrm{mL}, 2.0 \mathrm{mmol}$ ) and BuLi (about 1.6 M hexanes solution, 2.0 $\mathrm{mmol})$. The mixture was stirred for $15 \mathrm{~min}$ at this temperature before introduction of 2,4-dimethoxypyrimidine $(125 \mu \mathrm{L}, 1.0$ $\mathrm{mmol})$. After $2 \mathrm{~h}$ at room temperature, benzoyl chloride $(0.24$ $\mathrm{mL}, 2.0 \mathrm{mmol}$ ) was added at $0^{\circ} \mathrm{C}$. The mixture was stirred for $16 \mathrm{~h}$ at $60^{\circ} \mathrm{C}$ before addition of brine $(5 \mathrm{~mL})$ and extraction with $\mathrm{Et}_{2} \mathrm{O}(3 \times 10 \mathrm{~mL})$. The combined organic layers were washed with brine $(10 \mathrm{~mL})$, dried over $\mathrm{Na}_{2} \mathrm{SO}_{4}$, filtered, and concentrated under reduced pressure before purification by column chromatography on silica gel (eluent: heptane/EtOAc $8: 2)$. Compound $15(0.11 \mathrm{~g}, 45 \%)$ was isolated as a yellow oil.

38. Forbes, G. C.; Kennedy, A. R.; Mulvey, R. E.; Rodger, P. J. A. Chem. Commun. 2001, 1400-1401. See also: Balloch, L.; Drummond, A. M.; García-Álvarez, P.; Graham, D. V.; Kennedy, A. R.; Klett, J.; Mulvey, R. E.; O'Hara, C. T.; Rodger, P. J. A.; Rushworth, I. D. Inorg. Chem. 2009, 48 , 6934-6944. 